\title{
VISUALIZATION OF SOCIAL STRATA IN MEDIA
}

\author{
YULIANA MELKUMYAN
}

\section{Visual communication}

Visual communication is the process of information exchange through visual images. It is processed by the human eye. Vision has always been the predominant means of information consumption for human beings. Nevertheless, the fact that the amount of visual communications in the modern world is intensively increasing due to technological developments is irrefutable.

Formerly, nature (e.g. landscape, flora, fauna, body language and gestures, etc.) was the main source of visual information for human beings in the earliest stages of social development; later buildings, urban environment, machines, maps, fashion, all forms of arts enriched the visual context of social life; whereas photographs, movies, advertisement, computer animation integrated into our lives during the last century. Modern social life is overwhelmed by pictorial and filmic information due to the urbanization and commercialization processes, the emerging challenges of consumer society, technological progress and extension of the material world. These prerequisites contribute to the growth of visual communications in our daily life providing us with a number of diverse tools for not only the consumption but also for the production of visual objects.

\section{Peirce classification of signs}

Visual communication does not only refer to images by itself, the process of production and consumption of visual objects, but also to their meanings and the process of signification. Three types of signs are defined in Peirce's Semiotic Theory: Indexes, Icons and Symbols. Peirce classifies signs according to how their object functions in signification or how the objects determine their signs ${ }^{1}$. If the sign embraces some existential or physical connection with its object, then the sign is an Index. If the sign reflects the qualitative features of the object, then the sign is an Icon. If the sign utilizes some convention, habit, social rule or law that connects it with its object, then the sign is a Symbol' ${ }^{2}$. Thus, Indexes are physically rationalized, Icons function in virtue of qualities, and Symbols are conventional.

\footnotetext{
1 Peirce on Signs: Writings on Semiotic by Charles Sanders Peirce, Edited by James Hoopes, University of North Carolina Press, 1991.

2 Peirce's Theory of Signs in Stanford Encyclopedia of Philosophy (Retrieved from: https://plato.stanford.edu/entries/peirce-semiotics/), First published Fri Oct 13, 2006; substantive revision Mon Nov 15, 2010.
} 


\section{Symbolic Interactionism and Visual Communication}

According to the symbolic interaction theory the usage and interpretation of images are based on the culturally defined symbolic codes. People use symbols to create meanings to the world. Therefore, interaction is always symbol-based. Visual communication is only possible if the symbols used by the interlocutors produce the same cognitive images for all the participants of the communication ${ }^{3}$. Thus, culture depends on its participants who meaningfully interpret what is around them and "make sense" of the world in broadly similar ways.

Visual communication is getting much more coded, interactive, and influential. Visual perception is a complicated process that includes looking, seeing, reference, imagination, interpretation, and representation. These activities result in the reading of visual codes. Visual is a mode of understanding and analyzing social reality ${ }^{5}$.

\section{Visual images as a means for reproduction of power relations}

Apart from information exchange, images also perform aesthetic, documentary, commercial and ideological functions. Ideology is the knowledge that is constructed in such a way as to legitimate unequal social power relations ${ }^{6}$. In contemporary capitalist societies as in most other social formations, there are inequalities in the distribution of power and other goods. In order to sustain these structures of domination, the dominant groups attempt to represent the world in the forms that reflect their own interests, the interests of their power ${ }^{7}$. The power elites need visualization of inequalities since as Gillian Rose assumes the visual image is constructive of reality rather than simply being descriptive of it $^{8}$. As stated by Fyfe and Law images can depict social power relations ${ }^{9}$. While Marvasti asserts that everything we see is the basis for our knowledge about social life and social reality ${ }^{10}$. Thus, power relations and social inequalities are reproduced through visualization.

\section{Infinite semiosis of social stratification}

Images offer very particular visions of social categories such as class, gender, race, sexuality, and so on ${ }^{11}$. The post-Soviet development of Armenian society resulted in a huge variety of spontaneous and uncontrolled changes in

${ }^{3}$ Mead, G. H. Mind, self, and society: From the standpoint of a social behaviorist. (C. W. Morris, Ed.). Chicago, IL: University of Chicago Press (4)(PDF) Symbolic Interactionism, 1934. 2001, p. 6 .

Hall S. (1997a) "Introduction" in Rose G. Visual Methodologies, Sage Publications,

${ }_{6}^{5}$ Marvasti A. Qualitative Research in Sociology, Sage Publications, 2004, p. 67.

${ }_{7}^{6}$ Rose G. Visual Methodologies, Sage Publications, 2001, p. 70.

${ }^{7}$ Hodge R., Kress G. Social Semiotics. Cambridge: Polity Press, 1988.

${ }^{8}$ Marvasti A. Qualitative Research in Sociology, Sage Publications, 2004, p. 64.

9 Fyfe G., Law J. Picturing Power: Visual Depiction and Social Relations. London: Routledge, pp. 1-14.

${ }^{10}$ Marvasti A. Qualitative Research in Sociology, Sage Publications, 2004, p. 64.

${ }^{11}$ Rose G. Visual Methodologies, Sage Publications, 2001, p. 11. 
the social structure. Social polarization, increase in poverty, the formation of rich strata and the residual middle class are among those changes ${ }^{12}$. All these strata did not exist in Soviet society. The process of stratification in post-Soviet societies is totally different from that of Western countries. Therefore, the process of stratification and the visualization of social strata is an actual issue for social study in post-Soviet space. The visualized attributes of social status are tangible indices of social stratification.

Visual attributes of social strata that are produced and consumed in Armenian society are coded and signified conveying socially shared meanings. Symbolic codes of poor, middle, and rich strata are culturally defined. The idea of infinite semiosis by Peirce is applicable to the processes of visualization of the strata and class identity. The generated interpretant itself functions as a further, more developed sign of the object in question. Definitely, as a further sign, it will also signify that object through some features, which again, must be interpreted, and generated by a further interpretant. This leads to an infinite chain of signs. If any sign must generate an interpretant in order to be a sign, and any sign is itself the interpretant of some further sign, then clearly, there must be an infinity of signs both proceeding and preceding from any given instance of signification ${ }^{13}$.

\section{Visualization of "something that is absent"}

In his book "Ways of Seeing" John Berger stresses that "images were first made to conjure up the appearances of something that was absent"14. Admittedly, it is applicable not only in the visualization of either tiny (viruses, cells, small insects, etc.) or huge (countries, continents, planets, etc.) objects but also in portraying abstract concepts like happiness, poverty, inequality, stratification, etc.

In order to determine the status affiliation, different means of visualization are used. Hereby we will tackle upon visual attributes of poverty, middle class and wealth represented in media. Berger states that "images are more precise and richer than history"15. That means that capturing the modern patterns of visualization of the poor, middle class and the rich will enable us in identifying the cultural codes, which conjure up the appropriate meanings.

\section{Representation of social issues in media}

Hilgartner and Bosk argue that social issues compete with each other to get on the public agenda. Such competition is caused by the limitations of band-

${ }^{12}$ Melkumyan Yu. The Problem of Middle Class Construction in the Modern Armenian Society. Banber Yerevani Hamalsarani, Social Sciences, Economics, 138.5, YSU publishing, Yerevan, 2012, p. 8.

${ }_{13}$ Peirce's Theory of Signs in Stanford Encyclopedia of Philosophy (Retrieved from: https://plato.stanford.edu/entries/peirce-semiotics/), First published Fri Oct 13, 2006; substantive revision Mon Nov 15, 2010.

${ }_{11}^{14}$ Berger J. Ways of Seeing, British Broadcasting Corporation, 1972, p. 10.

${ }^{15}$ Berger J. Ways of Seeing, British Broadcasting Corporation, 1972, p. 10. 
width mass communication and public attention. New dramatic issues that coincide with the interests of power elites and the cultural preferences of society have the highest chance to get on the agenda ${ }^{16}$.

Media frames the social agenda. It is predetermined by media which social issues are of vital importance and how they should be represented. The attitude toward social actors, is shaped by copywriters, journalists and media companies. They choose the angle or perspective from which a story is told. Media is often supposed to be an objective and unbiased source of information. In fact, they just decide which part of the story to tell, which photo, picture or video documentary to broadcast from the near-infinite options. Constituting reality from various angles media represents its only partly. It is a selective process caused by not only political and ideological considerations but also by the fact that everything cannot be grasped in media.

\section{Study methodology}

To study the visualization of the poor, middle class and the rich in media the following research activities were implemented during June 2020:

- Visual analyses of 600 images of "Poverty", "The poor", "Wealth", "The rich" and "Middle class" in the result of Google search (the words were searched in 4 languages: Armenian, Russian, English and German),

- Visual analyses of 200 videos of "Poverty", "The poor", "Wealth", "The rich" and "Middle class" in the result of Youtube search (the words were searched in 4 languages: Armenian, Russian, English and German).

\section{Visualization of social inequality}

Stratification is defined by Pitirim Sorokin as a differentiation of social groups into classes and hierarchical ranking based on an unequal distribution of economical and power resources, various rights, duties, privileges and values. According to Sorokin's theory, social stratification is a social space with unequal vertical and horizontal distances, where the reference points in space are marked as the status of the individuals ${ }^{17}$. It is obvious that there is no society without stratification due to the ongoing processes of social differentiation and domination through the reproduction of power and inequality.

Overall, stratification may be defined as the system of institutionalized inequalities, which can be visualized to describe, depict and reproduce itself.

Sorokin suggests a multidimensional model of stratification and outlines three basic dimensions of inequality: economical, political and professional ${ }^{18}$.

${ }^{16}$ Хилгартнер С. Рост и упадок социальных проблем: концепция публичных арен // С. Хилгартнер, Ч. Л. Боск. Социальные проблемы: конструкционистское прочтение: хрестоматия. Казань: Изд-во Казан. ун-та, 2007, с. 145-184.

${ }^{17}$ Сорокин П. Человек. Цивилизация. Общество. М.: Издательство политической литературы, 1992.

${ }_{18}^{18}$ Ibid. 
In addition to these three dimensions, there are a number of characteristics that also constitute inequality: age, gender, nationality, education, culture, speech etc. Besides these social characteristics, there are a lot of attributes which identify the place of the individuum in the social hierarchy - clothes, cars, jewelry, leisure, hobby and profession-specific accessories etc. (See Picture $1^{19}$ ).

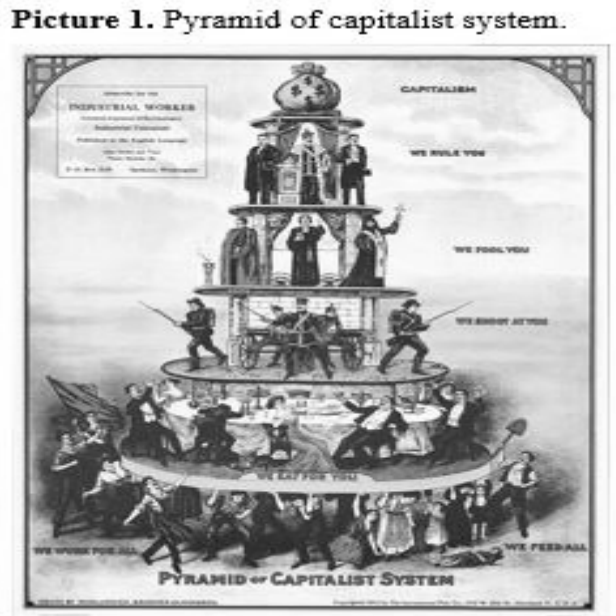

\section{Visualization of the poor}

Documentary photography is originally intended to depict poor, oppressed or marginalized individuals, often as part of reformist projects with the tendency to show the horror of their lives and, thus, inspire the change $\mathrm{e}^{20}$. The depiction of poverty is one of the most simplified ones since there are a number of visual stereotypes that create firm references to poverty in spectators' minds. Researchers on visual culture are concerned not only with how images look, but how they are looked at. They argue the fact that what is important about images is not simply the image itself, but how it is seen by a particular spectator in a particular way ${ }^{21}$. In this respect, media plays an important role both in creating the image of the poor and raising awareness of poverty. The way how the public perceives poverty largely depends on how it is represented by media. Nowadays, poverty coverage is very difficult to imagine without photos and videos, which are actively used by printed media, social media and television. Photos and videos frequently convey more impressive information than verbal or written text are able to communicate.

For describing poverty, one should take into account the following important aspects: consumer's objective capacities, consumer's subjective preferences, living conditions, value orientations, attitudes towards life goals and social achievements. Overall, poverty describes the social status of an individual or a social group highlighting how the poor are unable to meet the basic needs, lack the ability to work, etc.

However, for having a cohesive understanding of what is poverty the following questions should be answered: a) How do the poor live, what are their living standards? b) Where do they live? c) What is the poverty rate? d) Which

\footnotetext{
${ }^{19}$ Picture is retrieved from https://www.flickr.com/photos/iisg/7748272176/sizes $/ \mathrm{m} /(12.06 .2020)$.

${ }^{20}$ Rose G. Visual Methodologies, Sage Publications, 2001, p. 20.

${ }^{21}$ Ibid, pp. 11-12.
} 
social groups are poor? e) What kind of income sources do the poor have? f) What do they own? g) Which social goods are available for the poor? h) What does their ecological environment look like?

The answers to these questions give the following characteristics of poverty: physical discomfort (including hunger, deficient closet, indigent living conditions, lack of utilities, noisy and dirty environment, needy working conditions, etc.); poor health quality (short life span, frequent diseases, psychological instability, etc.); vulnerability, homelessness, high level of crime, violation of the law, unsteady socio-economic situation (low salary, financial dependence, etc. ${ }^{22}$; low level of education, low self-esteem ${ }^{23}$, unstable family situation, discrimination, alienation from the political processes ${ }^{24}$. These are the typical characteristics of poverty mostly met in different definitions.

When googling "Poverty" and "The poor" in these languages: Armenian, English, Russian and German, various images appear, which are culturally different, but are mostly identical with the meaning. The search result of the words "Poverty" and "The poor" mostly show people wearing old, oversized, shabby clothing, careless children, barefoot children and adults, poor housing conditions, dusty and dirty environment, small, dilapidated, dirty and grubby apartments, garbage, many children cosleeping, cold and hunger (See

Picture 2. Depiction of poverty in media.

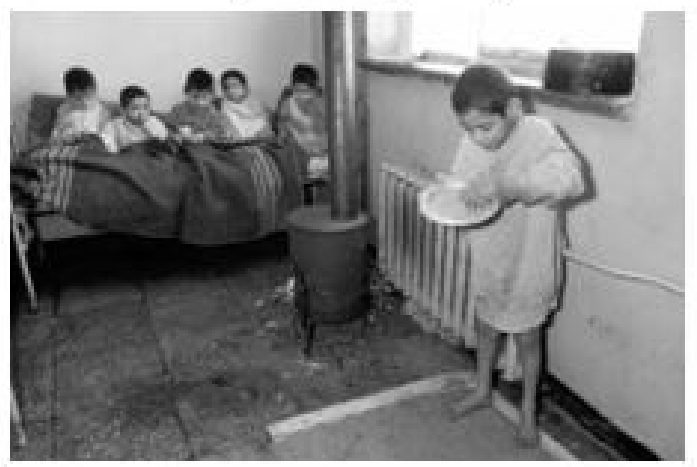
Picture $2^{25}$ ).

The search results of the word "Poverty" in the Armenian language are mostly documentary photos representing elderly people and children. The search results in Russian mostly render images of begging dirty hands (See Picture $3^{26}$ ), empty wallets, fistfuls of coins. Regarding the searches in English - images of beggars, homeless people, damaged old shoes, unhappy faces and curved backs are rendered. While searches in German mostly bring out maps and graphs showing the share of poor in the society while the personified pictures depict basically people of color (mostly children). It seems that western media are covering the issue of poverty more in the context of other countries (African, South American, Asian) to stress

${ }^{22}$ Schwartzman S. The statistical measurement of poverty. Rio de Janeiro, Brazil: Expert Group of Povertv Statistics. 2002.

${ }^{23}$ Sindzingre A. Values, norms and poverty: a consultation on WDR 2000/2001 poverty and development. Washington, DC: World Bank Group, 1999.

${ }^{24}$ Mckay A, Lawson D. Assessing the extent and nature of chronic poverty in low income countries: issues and evidence. World Development, 2003.

${ }^{25}$ Picture is retrieved from https://www. 1in.am/2080428.html (12.06.2020).

${ }^{26} \mathrm{Picture}$ is retrieved from https://www.24news.am/news/69239 (12.06.2020). 
the differences between those countries and the wellbeing level in their own country for their audience (See Picture $4^{27}$ ). Linking poverty with people of color forms associations like; "if poor then black" and vice versa "if black then poor".

Picture 3. Depiction of poverty in media.

Picture 4. Depiction of poverty in media.
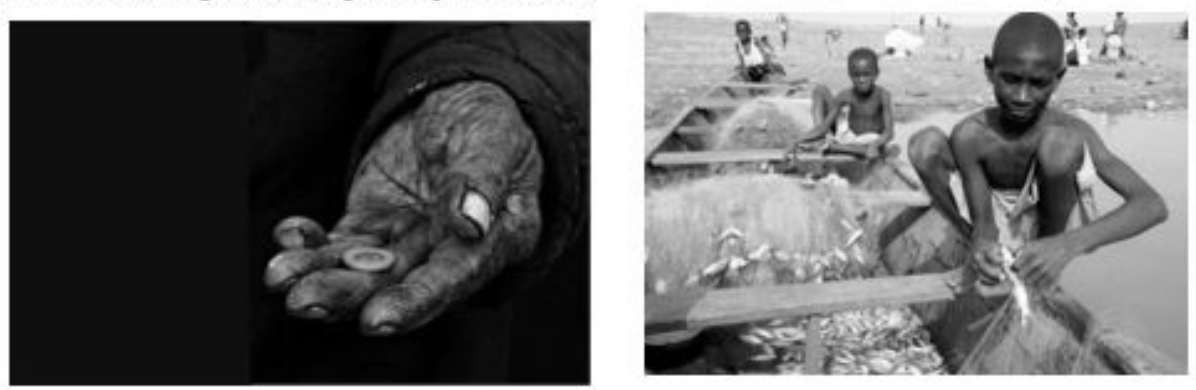

Poverty is associated not only with the general economic situation in the country but also with the lifestyle and personal qualities of the poor themselves (alcoholism, drug addiction, vagrancy, poor parenting, antisocial behavior, deviant behavior, crime, disability, etc. $)^{28}$. These components of poverty are easily transmitted through visual means. Such images not only reflect but also form the stereotypes and attitudes towards poverty from the position of power. As a result, the poor become an object of stigmatization and discrimination. Media, from this point of view, reproduces not only the stereotypes on poor people and form a special image of poverty, but create such cultural codes that link the poor people to dirt, garbage, carelessness, dilapidation, deviation, addiction and other disrespected forms of social behavior. Such semiosis contributes to further social exclusion of the poor.

The analyses of video and photo documents depicting poverty in media based on Peirce methodology shows that indexes (e.g. dirt, carelessness, cold, etc.) and icons (e.g. hungry children, homeless, begging hands, slum, etc.) are used more often than symbols (e.g. people of color) to visualize poverty.

\section{Visualization of the rich}

Wealth, as well as poverty, is perceived through the patterns of consumer behavior, which gives different opportunities to meet people's needs. Visualization of the poor contains obviously negative connotations, while visualization of the rich is ambivalent. The rich are usually represented through signs that have more positive or neutral meanings and conjure up the desirable standard of living and income.

${ }^{27}$ Picture is retrieved from https://www.dandc.eu/de/article/wie-alltaegliche-gewalt-armemenschen-die-armut-fesselt-und-was-dagegen-getan-werden-muss (12.06.2020).

${ }^{28}$ Белова Л. И. Конструирование образа бедности современными СМИ (социологический аспект) // Вестник Челябинского государственного университета, 2015, № 5 (360). Филология. Искусствоведение. Вып. 94, с. 58-64. 
While searching some depictions of the rich in Armenian, Russian, English and German languages very similar results are found. The means of wealth represented in the media are even more varied than that of the poor. The depiction of the rich communicates such signs that reveal high income, savings, prestigious level of consumption, possession of power, honorable social status, advantageous social networks. Rich people are usually represented in the media with such accessories as money, gold jewelry, thick purses, modern gadgets, big houses with tacky interiors, cars, yachts and private jets, security, expensive hobbies (e.g. playing golf, smoking cigars, luxury tourism, etc.).

Some pictures try to refocus the meaning of the rich from the material and financial well-being to the mental capacities, intelligence, harmonized human relations, etc.

Picture 5. Depiction of rich in media.

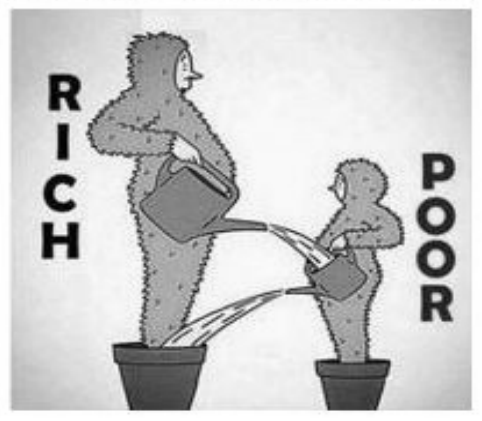

Picture 6. Depiction of rich in media.

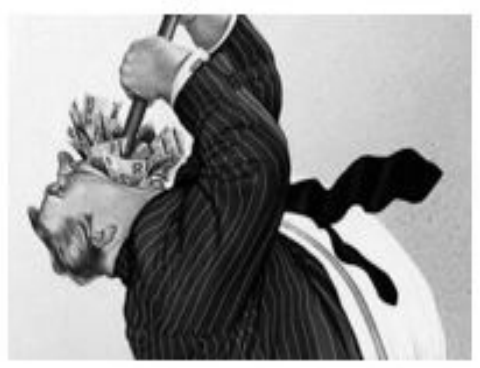

The negative image of the rich is supported by such pictures that demonstrate how their wealth is shaped through the unfair distribution of resources in the society, power relations and withdrawal or even stealing the money and other resources from the lower strata of society (See Picture $5^{29}$ ). Greed is another meaning that is usually visualized to stress the negative connotations of richness $\left(\right.$ See Picture $6^{30}$ ). In search of the rich, pictures of celebrities are found in the results.

In the visualization process of wealth, fewer indexes (e.g. big belly) and icons (e.g. celebrities) are used, whereas many more symbols (e.g. money, coins, gold, jewelry, etc.) are found in media instead.

On the one hand images of the rich are critical and stress the negative connotations of being rich - inequality, unfairness, greediness etc. On the other hand, images of wealthy people promote respect and acceptance, perceiving their prosperity as a reward for an extra effort. The shared symbols prompt the desire to possess them. Material wealth is the goal that is dreamt of and towards

29 Picture is retrieved from https://society6.com/product/rich-and-poor-illustration-thetruth_print (12.06.2020). (12.06.2020). 
which the majority of people aspire through education, employment and professional careers. Many feel embarrassed to talk about it out loud, but do have timid hopes to become rich anytime.

\section{Visualization of the middle class}

The concept of the middle class usually assumes a positive picture that includes an integrated society, a well-developed model of social compensation, a social group of people triggering social development and a specific lifestyle that stabilizes society. Such indispensable social functions are rarely attributed to the upper classes of society, and the wealth and the privileged position of the upper classes usually depends on middle-class potential ${ }^{31}$. Among the main indicators of the middle class are professional education, employment and the income derived from legitimate sources, which ensures a certain quality of life and have a tendency of an increase. The cost structure of the middle class is conditioned by income size and

Picture 7. Depiction of middle class in media.

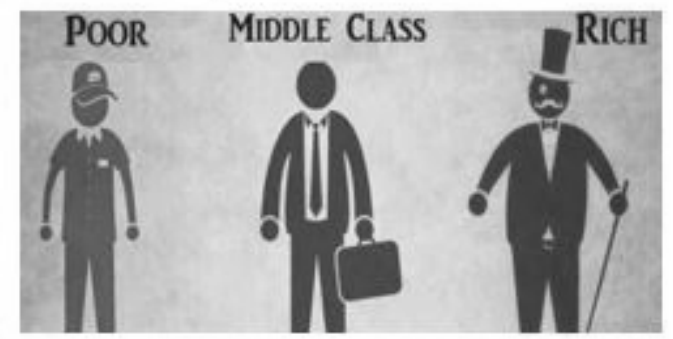
a value system. Consumption is a reciprocal process and a multi-functional meaningful social action that includes all the members of the society, who consider the consumption of others within the current social structure. Moreover, the consumption informs bystanders about the class identification of a particular consumer, shapes the image of the middle class, and conveys a particular social meaning to patterns of consumption ${ }^{32}$.

Lifestyle, preferable patterns of entertainment and leisure also put conventional boundaries between social strata and transmit value-based content of the middle class. Among the most popular leisure activities of the middle class are watching television, reading, listening to music, interacting with friends and relatives, hanging out in cafes and restaurants. Analyses of the leisure activities of the Armenian middle class show that it is not really filled with cultural events: visits to theatres, the opera and classical concerts do happen but only occasionally ${ }^{33}$. The lack of cultural saturation hinders the possibilities to depict it.

The analyses of the middle class's pictorial and filmic images found in search engines in English, German and Russian languages shows that the middle class is usually visualized in relation to the poor and rich strata (See Picture $\left.7^{34}\right)$. There are almost no indexes or icons used for the depiction of the middle

${ }^{31}$ Melkumyan Y. Armenia's 'Middle Class': Stability Characteristics and the Challenge of Erosion, - Caucasus Analytical Digest, Middle Classes, N 95, 30 May 2017 (http://www.laenderanalysen.de/cad/pdf/CaucasusAnalyticalDigest95.pdf)

${ }^{32}$ Ibid.

${ }^{33}$ Ibid.

${ }^{34}$ Picture is retrieved from http://myselfimprovementtoday.com/poor-vs-middle-class-vs$\mathrm{rich} /(12.06 .2020)$. 
class. The used symbols, which are vividly limited, are related to employment (e.g. business suit, case or laptop). Queries in Armenian failed to return even such results, showing instead pictures of the researchers linked to studies of the middle class in Armenia.

Being the biggest and at the same time socially, politically and economically the most important strata in the society, the middle class lacks the depictable characteristics in media. Thus, the motivation of being a middle-class representative is obviously not formed and the identification with the middle class is not substantial especially in the Armenian society.

\section{Conclusion}

The significance of images and visual communications is getting more and more powerful in the process of technological development. The visual image cannot be fully expressed through verbal means, it is perceived as a whole. Visuals are much more precise than the text and the perception of the world around us is mediated and settled by images.

To depict social strata, one needs a detailed definition of it to be able to conjure up the indexes, icons and symbols that refer the spectators to the culturally defined symbolic codes and communicate them through distinct cognitive images. Pictorial and filmic images of different social strata in media reflect the stereotypes and reproduce the social stratification system and social inequalities. As Berger says "they mystify rather than clarify". Due to its ideological function, visuals legitimize unequal social power relations. Pictorial and filmic images are used to sustain the structure of domination in society. Thus, visualization is an inherent part of the infinite semiosis of stratification processes and class identity.

Visualizations of the poor not only reflect but also form the stereotypes and attitudes towards poverty, stigmatize and provoke discrimination towards poor people. In spite of the critical representation of the rich through the depiction of inequality, unfairness and greediness, the visual attributes of wealth cause respect and stimulate acceptance among spectators, as long as material wealth is the goal that is dreamt of by for almost everyone. The middle class is usually visualized through indicators of "non-poverty" and "non-rich". Although it is the most important strata in society, the middle class lacks depictable characteristics in media. Thus, the motivation of becoming a middle-class representative is not formed clearly.

Overall, it is worth focusing on the fact that all visual images are constructive and can be deconstructed. The social stratification system can be deconstructed or reconstructed through visualization.

Key words: visual communications, social stratification, inequality, social strata, the poor, the rich, middle class, index, icon, symbol

\footnotetext{
${ }^{35}$ Berger J. Ways of Seeing, British Broadcasting Corporation, 1972, p. 11.
} 


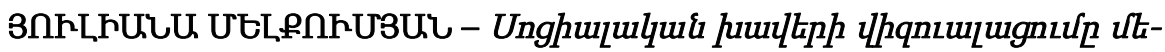

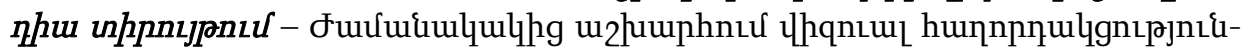

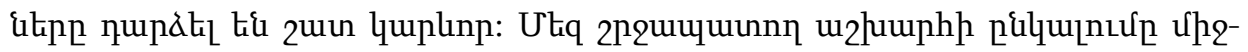

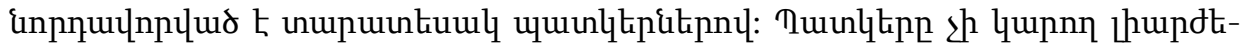

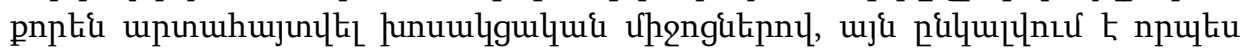

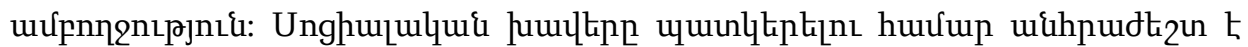

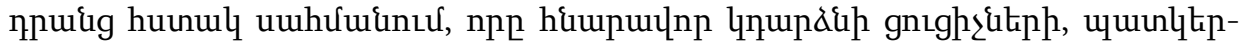

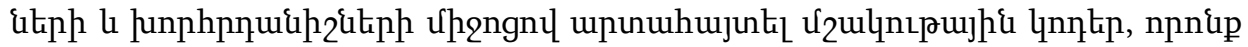

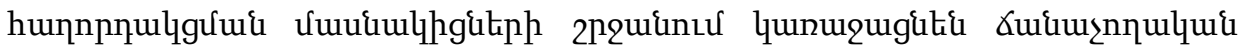

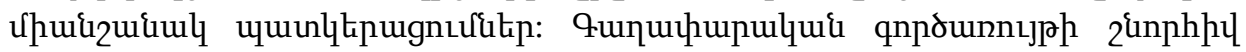

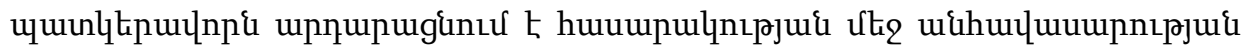

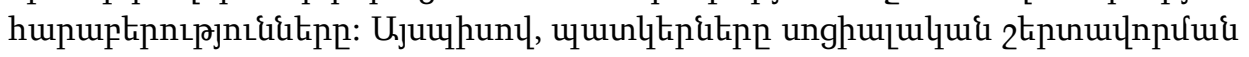

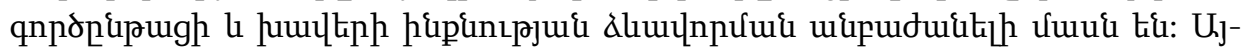

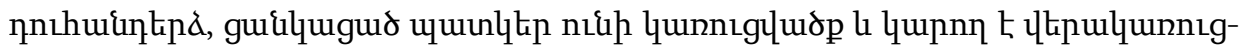

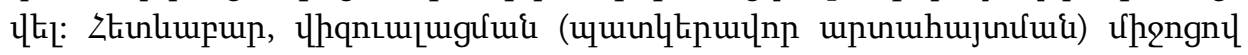

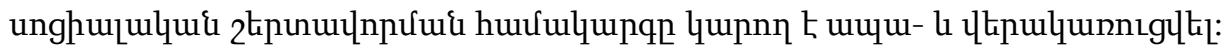

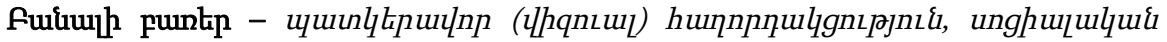

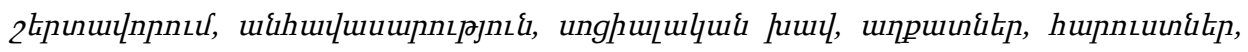

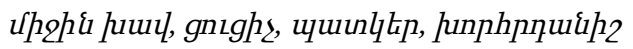

ЮЛИАНА МЕЛКУМЯН - Визуализация социальных страт в медиапроcmpaнстве. - Визуальные коммуникации получают сегодня всё большую значимость. Восприятие окружающего нас мира опосредовано визуальными образами. Визуальный образ не может быть полностью выражен вербальными средствами; он воспринимается как единое целое, а не последовательно. Для изображения социальных страт необходимо их детальное определение, которое дало бы возможность посредством индексов, иконок и символов выразить культурно специфические коды, которые создадут конкретные когнитивные образы у участников коммуникации. Благодаря своей идеологической функции визуальные образы обосновывают неравные властные отношения в социуме. Получается, что визуализация является неотъемлемой частью бесконечного семиозиса стратификационных процессов и формирования классовой идентичности. Тем не менее, любой визуальный образ - это конструкт и может быть деконструирован. Следовательно, посредством визуализации возможно деконструировать или реконструировать систему социальной стратификации.

Ключевые слова: визуальные коммуникачии, сочиальная стратификаџия, неравенство, соииальная страта, бедные, богатые, средний класс, индекс, иконка, символ

Utiplyujughltil t’ 04.06.2020

9pupunultil ť 09.09.2020

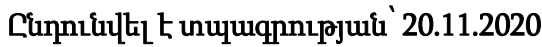




\begin{abstract}
Visualization of social strata in the media space. - Visual communication is gaining in importance today. The perception of the world around us is mediated by visual images. The visual image cannot be fully expressed by verbal means; it is perceived as a whole, not sequentially. To depict social strata, their detailed definition is necessary, which would make it possible, through indices, icons and symbols, to express culturally specific codes that will create specific cognitive images for the participants in communication. Due to their ideological function, visual images justify unequal power relations in society. It turns out that visualization is an integral part of the endless semiosis of stratification processes and the formation of class identity. However, any visual image is a construct and can be deconstructed. Therefore, through visualization, it is possible to deconstruct or reconstruct the system of social stratification.
\end{abstract}

Keywords: visual communications, social stratification, inequality, social strata, the poor, the rich, middle class, index, icon, symbol

\title{
About Authors
}

Yuliana Melkumyan - PhD, Associate Professor of the Chair of Social Work and Social Technologies, Yerevan State University

E mail: yulianamelkumyan@yahoo.com

\section{REFERENCES}

Hoopes, J. (1991) Peirce on Signs: Writings on Semiotic by Charles Sanders Peirce, University of North Carolina Press

Mead, G.H. (1934) Mind, self, and society: From the standpoint of a social behaviorist, (C. W. Morris, Ed.), Chicago, IL: University of Chicago Press (4) Symbolic Interactionism Hall, S. (2001) Introduction in Rose G. Visual Methodologies, Sage Publications, p. 6 Marvasti, A. (2004) Qualitative Research in Sociology, Sage Publications, p. 67 Doi: https://doi.org/10.4135/9781849209700

Rose, G. (2001) Visual Methodologies, Sage Publications, p. 70

Hodge, R. \& Kress, G. (1988) Social Semiotics. Cambridge: Polity Press

Fyfe, G. \& Law J. (1988) Picturing Power: Visual Depiction and Social Relations, London:

Routledge, pp. 1-14

Rose, G. (2001) Visual Methodologies, Sage Publications, p. 11

Melkumyan, Yu. (2012) The Problem of Middle Class Construction in the Modern

Armenian Society, Banber Yerevani Hamalsarani: Social Sciences, Economics, YSU publishing, Yerevan, p. 8

Berger, J. (1972) Ways of Seeing, British Broadcasting Corporation, p. 10

Hilgartner, S. (2007) Rost i upadok social'nyh problem: kontseptsiya publichnyh aren, Hilgartner, S, Bosk, Ch.L.Sotsial'nye problemy: konstruktsionistskoe prochtenie: hrestomatiya, Kazan, Kazan', pp. 145-184. 
Sorokon, P. (1992) Chelovek. Tsivilizatsiya. Obshestvo, Moscow, Izdatel'stvo politiocheskoi literatury

Rose, G. (2001) Visual Methodologies, Sage Publications, p. 20

Schwartzman, S. (2002) The statistical measurement of poverty, Rio de Janeiro, Brazil:

Expert Group of Poverty Statistics

Sindzingre, A. (1999) Values, norms and poverty: a consultation on WDR 2000/2001

poverty and development. Washington, DC: World Bank Group

Mckay, A \& Lawson, D. (2003) Assessing the extent and nature of chronic poverty in low income countries: issues and evidence, World Development Doi:

https://doi.org/10.1016/S0305-750X(02)00221-8

Belova, L.I. (2015) Konstruirovanie obraza bednosti sovremennimi SMI (sotsiologicheskii aspekt), Vestnik Chelyabinskogo gosudarstvennogo universiteta, No 5, (360). Filologiya. Iskusstvovedenie, 92, pp. 58-64

Melkumyan, Y. (2017) Armenia's 'Middle Class': Stability Characteristics and the Challenge of Erosion, Caucasus Analytical Digest, Middle Classes, N 95, 30, retrieved from: http://www.laender-analysen.de/cad/pdf/CaucasusAnalyticalDigest95.pdf Berger, J. (1972) Ways of Seeing, British Broadcasting Corporation, p. 11 